\title{
PAAUDŽU ATMIŅU CEĻOŠANA: IESKATS MUTVĀRDU VĒSTURES AVOTOS
}

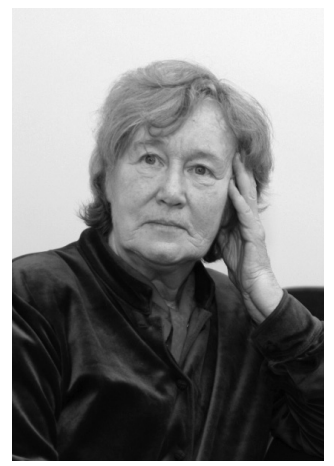

Māra Zirnīte. Izglīitība: Latvijas Valsts universitātes Vēstures un filologijas fakultātes diploms pielīdzināts filolog̣ijas zinātṇu mag̣istra grādam (2012). Nodarbošanās: atmiņu dokumentēšana, sākot ar Cilvēkarhīva programmu Latvijas Kultūras fondā (1987); veido Nacionālās mutvārdu vēstures krājumu un veic pẹtījumus LU Filozofijas un sociologijas institūtā (kopš 1992). Latvijas mutvārdu vēstures pētnieku asociācijas Dzīvesstāsts valdes priekšsēēētāja (www.dzivesstasts.lv). Publikācijas zinātniskos žurnālos latviešu, igauṇu, angḷu valodā; autore, redaktore un sastādītāja mutvārdu vēstures izdevumiem, digitālām audiovizuālām kompozīcijām.
Raksturvārdi: paaudzes, mutvārdu vēsture, dz̄ivesstāsts, vēstījums, atminu cel̦ošana.

\section{Ievads}

Cilvēki, izmantojot katrā laikmetā sev pieejamos kultūras resursus, atkal un atkal atgriežas pie savas pastāvēšanas pamatjautājumiem, apzinoties sevi kā pasaules pieredzes daḷu. Kad ierasto dzīvesveidu agresīvi pārtrauc revolūcijas, kari un citas kataklizmas, tas ne tikai izraisa fiziskas ciešanas, bet arī sagrauj morāli, atsviežot tālu atpakaḷ sabiedrības garīgo attīstību. Tad cilvēks atkal visu sāk no jauna, meklē savas eksistences morālo pamatojumu, pievēršoties arī tādiem avotiem kā atminas.

Raksta mērķis ir ielūkoties vecāko dzīvesstāstu autoru liecībās par notikumiem, kas iespaidoja dzīvi 20. gadsimtā, jo viṇu atmiņas savukārt veidojušas dzīves izpratni pēcnācējos. Individuālās pieredzes Nacionālās mutvārdu vēstures (NMV) krājumā ${ }^{1}$ var

1 NMV krājums LU Filozofijas un sociologijas institūtā. uzlūkot par literāri neapstrādātu izejmateriālu tautas vēstures stāstam par laikmetu, kas pārpilns satricinājumiem. Krasas pārmaiņas aizvien mobilizē atcerēšanos, liek katrai nākamai paaudzei uzdot jautājumus, lai savienotu pārrautos dzives posmus, skaidrotu savas eksistences pamatjautājumus un nākotnes iespējas.

Pievērsīšos atsevišksām dramatiskām epizodēm, kas attēlotas dzīvesstāstos un raksturo cilvēka pārdzīvojumu, kad tiek pārtraukts dabiskais dzīves ritējums. Atlasīti piemēri no atmiņām, kuru autori dzimuši 19. un 20. gadsimta mijā un jau no dzīves sākuma piedzīvojuši nemierus un varas maiņas. Vairākos dzīvesstāstos rodamās atsauces iepriekšējo paaudžu pieredzē atgādina vācu pētnieces Astrīdas Erlas (Astrid Erll) konceptu par atminu ceḷošanu ${ }^{2}$ starp paaudzēm kā nodrošinājumu atmiņu noturībai.

2 Astrīdas Erlas radīts jēdziens travelling memory, kas lietots arī, lai apliecinātu, ka atmiņa beidz pastāvēt, ja tā nepārceḷo starp cilvēkiem, grupām, valstīm. Šis koncepts izvērsts publikācijā par atmiṇu migrāciju starp Latviju un Zviedriju (Bela 2016). 


\section{Paaudzes nošķ̄irums}

Atmiṇu stāsti ir viens no veidiem, kā aplūkot paaudžu nošķīumu. Paaudzes piederību nosaka ne tikai dzimšanas gads, bet arī tādas pazīmes kā kopības izjūta ar laikabiedru likteni, vēstures notikumi, kas iespaidojuši dzīvi, pašidentifikācija ${ }^{3}$.

Paaudzes piederību var aplūkot, pamatojoties ne tikai uz ieskaņotā stāsta saturu, bet arī uz izklāsta veidu un sakārtojumu, valodas un izteiksmes līdzekḷu lietojumu, pasniegšanas formu.

Stāsta sniegumā atpazīstams individuālais kultūras resurss, ko raksturo sava laika izglītība, literārā pieredze, mantotie un aizgūtie runas paradumi. Tāpat kā uz folkloras priekšnesumu, arī uz dzīves izstāstīšanu var attiecināt valodas filozofa Džona Langšova Ostina (John Langshaw Austin) nostādni, ka valoda nav pasīvs līdzeklis īstenības aprakstīšanai, bet gan prakse, caur kuru īstenība tiek radīta un ietekmēta ${ }^{4}$. Stāstījums intervijā ir saistīts ar atmiņas aktivizēšanu, lai stāstītājs pārliecinātu par spēju pastāvēt mūsdienu pasaulē un rast savu vietu tajā. ${ }^{5}$ Šìs pazīmes intervijā neatklājas tik demonstratīvi kā priekšnesuma izpildījumā, tomēr atmiņu stāstos esmu saklausījusi gan pamācības, vēršoties pie iedomātas auditorijas, gan mērķtiecīgi atlasītus dzīves vērojumus, iedvesmas pilnu improvizāciju, kā arī nozīmes un jēgas meklējumus traǵisko dzīves notikumu atmiņās, par ko raksta antropoloǵe Vieda Skultāne'

Vēlos pievērst uzmanību izziņas slānim, ko sniedz literāri neapstrādātās runas pieraksts. Klausoties vai lasot atmiņu stāstus, nonākam personīgā attieksmē ar stāstīto, un tas kḷūst par mūsu nepiedzīvotās pieredzes daḷu, iedarbojoties gluži līdzīgi kā literārs darbs, kura autoram uzticamies. Turklāt katrā paaudzē var saskatīt raksturīgas individuālās runas iezīmes, kad arī uzrakstītā veidā izjūt cilvēka dzīvās runas skanējumu.

\footnotetext{
3 Mannheim 1952.

4 Austin 1962.

5 Par izpildījumu folkloristikā vairāk sk. Bauman 1989.

6 Skultans 1998.
}

Rolāns Barts esejā Teksta bauda ${ }^{7}$, aplūkojot mākslas teksta izspraukšanos caur laikmeta merkantilo dabu, tirgus reklāmu, politikas un dažādiem varas valgiem, min "ikdienišķā" valdzinājumu, kas piesaista lasītāju. R. Barts raksta: "Kāpēc daži (tostarp arī es) gūst baudu, redzot, ka vēsturiskos darbos, romānos, biogrāfijās tiek atspoguḷota kāda personāža ikdiena? Kāpēc tāda ziṇkārība par sīkumiem: dienas plānojumu, ieradumiem, maltītēm, dzīvesvietu, apgēerbu utt.? Vai tā ir "realitāte" ("bijušā" būtības) izfantazētā garša? Un vai tieši fantāzija nepiesauc "sīkumus", niecīgo, privāto ainu, kurā es itin viegli varu iederēties?"

Vecākās paaudzes atminu stāstos ieskanas gan seni vārdi, teicieni, tēlojuma pan̄ēmieni, gan ikdieniški sīkumi, kas piesaista uzmanību. Terēze Lazdina, dzimusi 1899. gadā Mežotniekos, Bauskas novadā, intervēta 93 gadu vecumā Anglijā, atceras no savām bērnu dienām šodien vairs nesaprotamu nodarbi: Tètis gāja sēt un es cēlos lìdzi - birzes ${ }^{9}$ taisīt. Cik tālu krīt sēkla - tik tālu noliek salmus, vienādi nosēj $k \bar{a}$ ar mašinu. ${ }^{10}$

Vārds raksturo stāstītājas bērnības laika saziņu, un šodien tā nozīme noskaidrojama, ieskatoties Mīlenbaha un Endzelīna Latviešu valodas vārdnīcā vai konversācijas vārdnīcās.

Literārā teksta ietekmi R. Barts uzrāda pazīmēs, kas raksturīgi dokumentārajiem autentisko atmiņu vēstījumiem. "Ja būtu iespējams iztēloties tekstuālās baudas estētiku, tajā būtu jāiekḷauj rakstīšana skạ̦ā balsī." "I1 Stāstītās atmiņas ir sava veida šāds bals̄̄ fiksēts teksts. Tas savu skanējumu saglabā arī rakstveidā. Piemērā Alvīne Mūrniece (dzimusi 1906. gadā Lūžņā, intervēta turpat 1985. gadā) lībiskā dialektā stāsta par to, kā apcietina vinas vīru Ernestu, tikko ǵimene pēc Otrā pasaules kara atgriezusies savā piejūras ciemā, no kura vācu militārā administrācija visus bija pārvietojusi uz iekšzemi.

\footnotetext{
7 Barts 2012, 52.

8 Turpat.

9 "Birzes platums (starp divām vagām) bija ap 7-10 pēdas.” ME I, 299; Konv. vārdn, 2, 3205.

10 NMV-63.

11 Barts 2012, 63.
} 
Jā, nu mēs ir mäjas. Nu ir kriev. Nu n,em akal kopa tos vīrs, nu las kopa tos vīrs - Ernest un Ernest brāl Fric un Jān, un viss, kas tik nu ir. Četrs brāls pan̄èm uzreiz. Un nu aizved uz Anc vins, un ieliek pagraba tos vīrs. Ieliek tos vīrs pagraba. Un kā nu bij, kā ne, Ernests man dabuj pazinnot, lai es vinam kaut ko aizved ēst. Jā, otra diene es sadabu viss, ko nu varej, sadabu vinam, aizved. Tas sargs, kas pie tiem durvim stāvej tai pagraba, tas uzreiz iesaucas: "Mūrnieks ar! Apžēlojas, Mūrnieks ar iekš tai pagrabāa!”, to par man vīr viš teic. ${ }^{12}$

Apcietinātais Ernests Mūrnieks bija apkārtnē labi pazīstams kārtīgs mežsargs. Arī to, kā vīrs pirmoreiz atgriežas no izsūtījuma Sibīrijā, Alvīne pastāsta tēlaini ar ritmiskiem atkārtojumiem: Un nu laiž mājas. Un Ernests ta bij mājas. Un, ka Ernest laid mājas, viš nevarēj pār smilg pārkapt - tai pirma reize. Viš pa smilg nevarēj pārkapt. ${ }^{13}$

Savus pēdējos mirkḷus, atstājot iekopto mājvietu Zemgalē, kā spilgtu gleznu atceras Valida Danenberga (dzimusi 1914. gadā Dobeles novadā, intervēta 1992. gadā Almēlijā, Anglijā):

Visi lauki pilnīgi zeltoja, gan kaimiños, gan mūsu lauki. Bija plaujamais laiks, kad mēs atstājām māju. Tieši bija rudzu plaujamais laiks. Kvieši palika dzelteni. Un cik tikai varēja pārredzèt, visu kaimiņu lauki bija brīnišķīgi. Bija laba raža. Tas bija jūlijā. Un tad nu sirds sāpēja gan briesmīgi. Un bija ziņa, ka krievi nāk otro reizi iekšă.$^{14}$

Līnai Kuǵei pašai bija bagāts folkloras pūrs, un viņas atmiņu stāstā arī rakstītā veidā var saklausīt valodas ritmu, dziedošu intonāciju, senus vārdus un tēlainus salīdzinājumus.

Tas varēja bùt apmèram ap 1850-to gadu, kad mans vecaistēvs bijis jauns puisis un strādājis drēbnieka darbu. Nav zināms, kur viņš mācījies, kur nē, bet meistars bijis slavens. Gājis no mājas uz māju un šuvis bikses, vestes un svārkus, bez mašinas, tikai ar rokām. Un galvenais - pliķos kažociņus. Toreiz tāds bijis katram cilvēkam, vai viņš bagāts vai nabags, pliķais kažociņš kā piederīgs pie visa apgèrba. Tã nu viņšs staigājis, šuvis, bijis priecīgs savā amatā un iecienīts cilvēkos. Vēl otrs amats vinam bijis dziednieka amats. Viņš gājis no mājas uz māju, strādādams savu drēbnieka amatu un vēl to dziednieka šepti piekopis. Kulīte mūžñgi nēsājis lìdzi radzinus, podinus, izpalīdzējis cilvēkiem, kur tikai kāda sāpēšana. Bijis arī taupīgs, neskrējis uz krogu, tā kā citi puiši. Bet savas kapeikas krājis nebaltām dienām. Tāds bija mans têva tēvs.

Un tā nebaltā diena arī pienākusi. Pienākusi ar precēšanos. Jo bijis ieskatījies vienā apal̦ā, plikā bārenītē. Kurai nebijis nekā pūrā kā tikai tas svārciņ̌s, ar kuru viņa gājusi pie iesvètī̌šanas, un tā villainìte. Tas bijis viss vin,as pürs. Nu, uz precēšanos viņ̌s savu lìgavu aplam skaisti izgèerbis. Pat kurpes nopircis. Bet tās kurpes, tās viņas kājai bijušas tik nepierastas un cietas. Pārgājusi no baznīcas, novilkusi kurpes, uzāvusi pastalas un nodancojusi savas kāzas ar pastalām. [..]

Bet ta nu sākuši birt tie bērni. Biruši tā $k \bar{a}$ purva strazdinam - cits pēc cita, cits p $\bar{e} c$ cita, septini gabali. Mans tềvs bijis tas pēdejais, tas septītais. ${ }^{15}$ (Līna Erna Hermīne Kuğe, dzimusi 1910. gadā Zvārdes pagastā, intervēta 1996. gadā Dobelē.)

Dzīvesstāstu izteiksmes veids atklāj paaudzi raksturojošu saziņas kultūru, kurā atspogul’ojas gan valodas vide, gan lielā mērā - folkloras iespaids un stāstniecības tradīcija, kas uzturējusi dzīvu atmiņu miju starp paaudzēm, iesaistot personīgā pieredzē arī to, kas piedzīvots vectēva un vecāsmātes jaunības dienās.

Igauņu salīdzinošās folkloras pētniece Tīu Jāgo personīgo atmiṇu stāstu pētniecību nosauc par pārmantojamo vēsturi: "Dzīvesstāstu vai patiesu dzīves notikumu pasniegšanas tautiskās vēstījuma formas mainās līdzi laikam. Pētot pārmantojamās vēstures ietvaros patiesu notikumu atspogulošanas paņēmienus un formas, iespējams novērot arī pārmantošanas procesu (pārmantošanas parādību pastāvīguma un izmaiņu līdzsvaru)." 16

\footnotetext{
15 NMV-748.

16 Jāgo 2007, 112.
} 


\section{Paaudžu skatījums mutvārdu vēstures avotos}

Dzīvesstāsti raksturo personīgo skatîjumu sociālajā vēsturē, kurā notikušas divas revolūcijas, divi pasaules kari, divas lielvalstu okupācijas; neatkarīgas valsts tapšana, zaudēšana un atjaunošana ${ }^{17}$. Viena cilvēka mūžam par daudz, tomēr atminu pavedieni sien paaudzi pie paaudzes un ļauj šo laiku pārredzēt un vērtēt no vēstures subjekta viedokḷa. Nenorobežojoties no pārmain̄ām, kas skārušas ne tikai Latviju, bet visu pasauli un par ko vēsta arī ārzemēs ierakstītie kādreizējo Latvijas iedzīvotāju dzīvesstāsti.

Ja salīdzina vecākās paaudzes autoru dzīvesstāstus, kas ierakstīti Latvijā un ārzemēs, var saskatīt lielas līdzības. Atšķiras sižeti vēlāko dzīves notikumu norisēs, tomēr stāstījums risināts no līdzīga skatpunkta, individuālais liktenis saistīts ar tautas kopīgo pārdzīvojumu. Antropoloǵe Vieda Skultāne saskata Latvijā ierakstītajos vecākās paaudzes dzīvesstāstos saskaņojumu ar literāro tradīciju ${ }^{18}$. To pašu var attiecināt uz atmiņu stāstiem, kas ierakstīti ārzemēs, - pagājušā gadsimta sākumā dzimušos vieno neatkarības gados gūtā izglītība un kultūras pamats, kam atsauces rodamas latviešu literatūrā, folklorā, etnogrāfijā, mūzikā, mākslā. Atpazīstamība parādās interpretācijās, kultūras attieksmju daudzveidībā un dzīves vērtību kritērijos.

Nākamās - trimdā augušās - paaudzēs piederības apziņa sazarojas atkarībā no paaudžu atmiņu mantojuma, gimenes iespaida un personīgās izvēles. Kā raksta Inta Gāle-Kārpentere: "Trimdas identitāte izauga no tām neizsīkstošajām sarunām, kuras tieši un netieši uzturēja latviešu sakarus. Vispamatīgāk un vispersoniskāk trimda substancionalizējās nostāstos, kas, transformējoties dzīves un tautas vēsturē, vienlaikus bija arī identitātes veidošanas

17 Precizējot: vardarbību un varas mainas iedzīvotāji pieredzēja vēl biežāk, arī 1915.-1918. gadā, kad Latvijas teritoriju okupēja ķeizariskās Vācijas karaspēks; 1918.-1920. gadā, kad valdīja padomju diktatūra un notika Latvijas Neatkarības karš.

${ }_{18}$ Skultans 1998, XII. un uzturēšanas līdzeklis."19 Tādējādi kultūras piederības izjūtu trimdas apstākḷos lielā mērā izškīira atminu stāsti, kas ceḷoja no vecākiem pie bērniem, starp grupām, kopienām, individuāli un publiskos sarīkojumos, vasaras nometnēs.

Turpretim represēto vai dažādu kultūras traumu pieredzējušo cilvēku atmiņās paaudžu piederību nojauc dabiskās dzīves attīstības pārtraukums. Ārkārtas situācijā meitai nākas uzṇemties mātes lomu, ja brālì/māsas kḷūst bāreṇi vai arī meita kḷūst māte savai mātei (Noras Ikstenas romānāân ${ }^{20}$ attēlotā situācija sastopama arī atminu stāstos). Cilvēki stāstos cenšas rast absurdās pieredzes skaidrojumu, atgūt piederības izjūtu un pamatu, lai dzīvotu tālāk. Tad atbalsts rodams iepriekšējo paaudžu garīgajā mantojumā, dzimtas pēctecības apzin̄ā. Starp personībām, kas spējušas savu smago pieredzi pārvērst stāstā un plaši dalīties ar to sabiedrībā, var minēt Melāniju Vanagu²1, Vladislavu

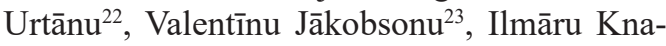
ǵi ${ }^{24}$, Andu Līci ${ }^{25}$, Benitu Kalniṇu ${ }^{26}$. Atsauces īsten̄̄bā piešḳir atmiņu stāstiem augstu morālo statusu.

Nacionālās mutvārdu vēstures krājumā apvienotie dz̄ivesstāsti atklāj arī paaudžu atmiņu satikšanos, savstarpējo mijietekmi. Minēšu divus piemērus vecvecāku atminu lomai personīgo uzskatu tapšanas un sevis apzināšanās procesā, par ko runā mazmeitas: Anita Timane, kas dzimusi 1960. gadā Londonā, un Elīna Grīniece, dzimusi 1985. gadā Rīgā.

Mana vecmamma ieradās [Londonā] 1967. gadā, kad man bija septini gadi. Un tad vina mums visiem stāstīja to realitāti, $k \bar{a} d a$ tā bija Latvijā sešdesmit septītā gadā, par kolhoziem, un par visu, ko vina bija novērojusi. Un tie stāsti bija diezgan komplicēti un dramatiski, un vinga pati bija tāda diezgan laba stāstītāja, tā kā viņa varēja izstāstīt arī. Tā kā tas, es domāju, mani loti iespaidoja. Viens otrs

\footnotetext{
19 Inta Gāle-Kārpentere 1994.

20 Ikstena 2015.

21 Vanaga, Melānija 1991; 1995-1998.

22 Urtāns, Vladislavs 2015.

23 Jākobsons, Valentīns 2006.

24 Knaǵis, Ilmārs 2016.

25 Līce, Anda 1990-2008.

26 Kalnina, Benita 2008.
} 
saka, ka mēs bijām diezgan līdzīgas. ${ }^{27}$ (Anita Timane, dzimusi 1960. gadā Londonā, intervēta 2009. gadā Rīgā.)

Vecāmāte no tēva puses bija izsūtīta uz Sibìriju kā astonpadsmit gadīga meitene. Viña loto daudz stāstīja par to, kā Sibīrijā gājis, bet tas notika diezgan vēlu, kad mēs jau bijām tādi divdesmitgadīgi. Tajā laikā mēs to visu bijām skolā mācījušies un filmās skatījušies, ko tas tragiskais vēstures konteksts nozìmē.

Mani vecvecāki vienmēr uzsvēra, ka viņiem nebija Sibìrijā tas trakākais variants. Viñi Tomskas apgabalā tika aizsūtīti bez nekā, bet diezgan àtri atrada mājas vietu, iekopa māju, kopīgi iedzīvi radīja. Vecāmāte Sibìrijā iepazinās ar manu vecotēvu, apprecējās, Sibīrijā piedzima tēvs. Viņi atgriezās, kad manam tēvam bija mēnesis. Pats neko neatceras. Bet viňš ir braucis studentu grupā uz Sibīriju jaunības dienās. Aizbrauca apskatīties. Vin̄u l’oti interesēja. ${ }^{28}$ (Elīna Grīniece, dzimusi 1985. gadā Rīgā, intervēta 2017. gadā Rīgā.)

Klausoties vienas dzimtas dažādu paaudžu stāstos, var vērot, kā motīivi turpinās, ieplūst cits citā, sasaucas vai gluži otrādi - tiek noraidīti un pārveidojas. Elizabete Janelsiņa savā atminu stāstā iekḷauj mātes stāstīto par došanos projām no Latvijas Otrā pasaules kara beigās. Viegli uztveramā smeldze izsaka arī stāstītājas attieksmi pret apstākḷu spiesto aizcel̦ošanu, kas nebija pašu izvēle.

Un tad vinga palikusi viena pati, vinga bija pan̄emusi mazu somiņu, kaut ko tur ielikusi iekšā un aizgājusi uz pēdējo kuği un arī aizbrauca uz Vāciju. Un tad viña teica - viña bija braukusi ar ormani uz turieni - un tas ormanis teicis: Jā, jā, kundzìt, tagad, kad ir slikti laiki, tad jūs visi brauciet prom, bet mēs paliekam-mēs to izturēsim, un gan jau varbūt jūs atkal kädreiz brauksit atpakal,. Un pa tiem gadiem viña to l,oti daudzreiz pieminèja - tā ka vajadzejja palikt. ${ }^{29}$ (Elizabete Janelsiņa dzimusi 1923. gadā Rīgā, intervēta 1996. gadā Rīgā.)

\footnotetext{
27 NMV-3441.

28 NMV-4489.

29 NMV-480.
}

\section{Vecākās paaudzes atmiṇu vēstījumi}

Subjektīvais cilvēku vēstījums visskaidrāk izpaužas dzīvesstāstu audio ierakstos un tuvu tekstam lasāms interviju rakstiskā atveidojumā. Turpinājumā sniegšu atsevišķus garākus atmiņu fragmentus, l,aujot lasītājam iejusties izteiksmes veidā, valodas ritmā, stāstītāja attieksmē pret notikušo. Sekojošos piemēros nav iekḷautas akustiskās nianses (izsaucieni, nopūtas, smiekli), skaidrības labad reizēm mainīta vārdu kārtība un svītrotas atkāpes no sižeta. Atsevišķie teksta izlaidumi atzīmēti ar divpunkti kvadrātiekavās.

Kad 1992. gadā Anglijā intervēju divas 90 gadus vecas kundzes, mani pārsteidza viṇu spēja sīki izstāstīt agrā bērnībā un jaunībā pieredzēto. Pieaugot manai intervētājas pieredzei, sapratu, ka šāda spēja, pat sasniedzot simt gadus, nav izñēmums. Atmiņas palīdzējuši uzturēt arī stāstītāju dzīves apstākḷi - abas stāstītājas dzīvojušas lielākoties starp latviešiem, noslēgti no sabiedrības Lielbritānijā.

Adelīna Rozīte, kaut arī piebilst Bet mans mūžs ir dikti tāds grūts, es nezinu, vai es visu varēšu izstāstīt, tomēr skaidri spēj attēlot savus agrīnos mūža pārdzīvojumus. Viņa dzimusi 1899. gadā, un dzīve sākās ar satricinājumiem, kā viss 20. gadsimts. Adelīnai bija seši gadi, kad dumpinieki tēvu ar varu grib iesaistīt muižas dedzināšanā, bet pēc tam soda ekspedīcija - vainīgo uzrādīšanā. Tēvs nepiekāpjas ne vieniem, ne otriem - no nemierniekiem paslēpjas mežā, bet nevienu nenodod, kaut pašu pieliek pie lielā bèrza. Mans têvs bija dzelzcelnieks. Lai nebūtu jāiet karadienestā 25 gadus, viņš iestājās 20 gadu vecumā dzelzcel̦a dienestā, bija strādnieks. Un piektā gadā vin,š jau bija precējies un vinam bija gimene. [..] $\mathrm{Nu}$ piektā gadā pirms Ziemassvētkiem tad tā revolūcija sākās, un tad cilvēki apbrunojušies ne jau ar šaujamiem, bet ar cirvjiem, ar lāpstām, ar grābeklıiem, ar sakumiem, ar dakšām nāca un visus dzelzcelniekus, kurus tikai varēja dabūt, vīriešus, visus ar n̦ēma lìdzi. Un tad gāja to pili dedzināt tam fon Zìvertam.[..]

Es maziña biju. Piecus kilometrus no Skrīveriem un piecus kilometrus no Jumpravas, tur pa vidu man tēvs dzīvoja. Skrīveru muiža no mums kādi 3 vai 4 kilometri uz Daugavas krasta, tā bija pils. Un tad viņi aizgāja 
uz to pili visi tie dedzinātāji un aizdedzināja to pili. [..]

Sestā gada janvārī nāca kazaku vilciens un apturēja pie mūsu mājiņas, un pārmeklēja ieročus. [..] Nu un tad papu izsauca ārā tas virsnieks un nolika pie bērza, pie mūsu mājas bija tāds liels bērzs. Un prasīja, lai uzrāda, kur ir tas Prekavu Tomsons, tas vadītājs revolūcijas. Man tēvs sacīja, ka vin̄š nezina, tādu viņš nemaz nezina un nepazīst, un nav redzejjis un nezina. Un tad vinam draudēja tas virsnieks, ka, ja izrādīsies, ka viņš ir zinājis un neteicis, tad viņu un visu to gimeni nošaus pie tā bērza. Un to visu tēvs uzn̦ēma tā stāvot, nebija sabrucis.

- Tad jūsu vecāki nebija dedzinātāju pusē?

- Nè, nēe. Mès bijām cara cilvēki. Mums pie sienas vienmēer karājās cara lielā bilde ar elllas krāsām. ${ }^{30}$ (Adelīna Rozīte, intervēta 1992. gadā Straumēnos, Anglijā.)

Adelīnas ǵimene neatbalsta revolūciju. Šajā gadījumā atmiṇu stāsts atgādina, ka notikuma laikā valdīja dažādi uzskati. Piektā gada dumpiniekus neatzina arī Ernests Mūrnieks (dzimis 1902. gadā Popē), kura tēvs un arī pats bijis mežsargs un uzturēja kārtību Popes muižas meža apgaitā. Tas netraucē pasmieties par baronu un nepatīkamo elkoņa bučošanas paradumu. Ernests ar smīnu savā ventiņu izloksnē (Ernests dzimis Popē un Lūžņas ciemā ir ienācējs) stāsta par vietējo ḷaužu un muižas attiecībām. Bet postīt un graut - tas ir sabiedriskās kārtības un attieksmes jautājums, kas nav pieñemams ne Ernestam, ne Adelīnai.

Pats tač es ar atceros, ka bij baron laiki, ka bij baronam rok jālaiz. Pats ir to darījs uz jakt, ka bij. Viš tev iedod ābol, piemēram, jeb ko, tas jau to nozìmē, ka viš gaid... nu, ko ta tu darīs! Tēvs bij mežsargs. Ja es nedarìt to, ta tam tēvam sliktāk par to, pats par sev.

Tāds gadījums ir bijs ar mūs Popes baron. Vinam bij vecs, uzticams mežsargs, kas māk gèégers izstādìt zināmā vietā. Katrs to nevar. Viš ir aizgājis pie to baron Popē, kā jau parasti, nobučo rok. Un tas dēls ir bijis, es neatminas, desmit vai diupadsmit gāad. desmit gād laikam. Nu bērnam tač nebučos rok. Tas

30 NMV-57. vecais ir teics: "Ja tu man dod god, tad tev manam dēlam ar ir jādod god!’ Saprot, ko! Vecais mežsargs ir teics: "Es tač domāj, ka tas ir bērns, ka to tač man nebūt tā jāgoda." "Nē, nēe, ja tu man dod god, ta tu manam dēlam ar iedod god!" tā teics. ${ }^{31}$

Toties Līnu Pināti revolūcija pievelk. Uzaugusi kreisi noskaņotā ǵimenē, kas arī Piektā gada revolūcijai deva savu upuri, - 13. janvāra demonstrantu apšaudē ${ }^{32}$ iet bojā brālis. Kad pati nokḷūst Maskavā, 1917.-1918. gadā darbojas laikraksta Izvestija ${ }^{33}$ redakcijā. Uzskati ir dažādi - politika iezīmē šķirtni vienas paaudzes robežās. No tā izriet konflikti, kas gan Latvijā visbiežāk tiek ienesti no ārienes.

Tas bija 1917. gadā, kad bija šitā Februāra revolūcija, turpat gandrīz gadu, un tad vēl sliktāk palika. Tad jau es biju... no tiem amerikāñiem es aizgāju, kad nogalināja to vācu sūtni, kad bija atentāts ${ }^{34}$, toreiz jau àrzemniekus visus izsūtīja, un tad man labie apstākli tajā rūpnīcā beidzās [..]. Es biju rēkinvede, vecākà rēkinvede Izvestijas redakcijā, tad jau tas bija dienas kārtībāa, tad es visam sekoju. Tā bija komunistu prese, komunistu kantoris, divi veci bolı̌seviki par mani galvoja, citādi tur nevarēja tikt iekšā.

Līna Pināte 1920. gadā atgriežas Latvijā. Līdz mūža beigām strādā par finansisti-revidenti, pensijā aiziet ar 70 gadu darba stāžu. Atceroties par revolucionāru iznīcināšanu Krievijā, atzīst, ka varējusi būt viena no viņiem. Taisnību sakot, ja es būtu precējusies, tad manis sen jau nebūtu, tad Sibīrijā mani kaulini bütu nolikti. Man bija tik interesanta sabiedrība, tāpat vīriešu sabiedrība, kas jau kaut kas bija un kaut ko nozìmēja. Tos vienkārši izsūtīja. Tad jau es arī būtu piederējusi

31 NMV-1.

32 1905. gada 13. janvāra karaspēka uzbrukums demonstrantiem Daugavas malā pie dzelzceḷa tilta.

33 Laikraksts, dibināts Krievijā 1917. gada Februāra revolūcijas laikā.

34 1918. gada 6. jūlijā atentāts pret Vācijas sūtni Krievijā Vilhelmu fon Mirbahu tiek uzskatīts par kreiso eseru mēǵinājumu izprovocēt jaunu karu starp Vāciju un Padomju Krieviju. 
pie tiem. ${ }^{35}$ (Līna Pināte, dzimusi 1897. gadā Elejā, intervēta 1991. gadā Rīgā.)

Savukārt Elizars Rabinovičs vērojis Piektā gada nemierus kopā ar tēvu Jelgavā. Tā ir neliela epizode atmiņās, ko intervētāja Ināra Reine uzklausīja Kalifornijā 1999. gadā, kad stāstītājam bija 101 gads. Elizars savu attieksmi pret nemieriem tieši neizsaka, līdzīgi kā viņa vecāki, kas notikumus vēroja, bet paši nepiedalījās.

Es esmu dzimis 1898. gadā 24. decembrī, Jelgavā. Tēvs bija skroderis, māte bija cepurniece. Abi divi ebreji. Vectēvs no tēva puses bija muzikants. Spēlēja ballēs, baroniem, ebreju kāzā̄s. [..] 1905. gadā mēs dzīvojām Marijas ielā, tā drusciṇ no sāniem bija Alus fabrika. Un vienu reizi mēs skatāmies - strādnieki pāri pa sētu, un bēg projām. Tēess stāstīja, ka tur bija nemieri fabrikà un tur bija izsaukti kazaki un tie ar nagaiku [pātagu] sāka sist vinuus un viñi muka pāri sētai. Atceros, ka bija mītiņš Strēlnieku dārzā. Es ar tēvu arī aizgāju. ${ }^{36}$

Turpinājumā vēl viena epizode no Adelīnas Rozītes atmin̄ām. Kad vinai ir sešpadsmit, tuvojas Pirmā pasaules kara fronte un gimene dodas bēgḷ gaitās uz Vitebskas guberņu. Seko slimības, bads, nomirst vecmāmina. Taču lielākās briesmas pati piedzīvo 1918. gadā, kad pēc revolūcijas Krievijā plosās Pilsoṇu karš. Tolaik viņa strādā dzelzceḷa rēḳinvedībā un brauc līdzi vilcienam.

Nu tad mès aizbraucām uz Ribinsku, un tur bija pavēle likvidèties. [..] Pa to laiku es uz Ribinsku gāju tāpat intereses pēc apskatīties pilsētu. Komunisti virsniekus, cara laika virsniekus, kas bija formās, tos šāva kā sunus, bez kādas tiesas un izmeklēšanas. Turpat, kur viņš gāja, turpat arī viņu nošāva. Tās bija briesmas, ko es tur redzēju. Biju iegājusi vienā apavu veikalā, kur labo apavus, un tur strādā divas jaunas meitenes, un es prasīju, ka man vajadzētu kurpēm papēžus pielikt, vai te neviena nav, kas to izdarītu. Vinas saka, mēs esam tās kurpnieces, mēs to darām. Mès iepazināmies, vinas man tūlīt prasa, kas es esmu. Es vaļsirdīgi visu izstāstīju, ka es esmu iebraukusi

${ }^{35}$ NMV-3095.

${ }^{36}$ NMV-803.
Ribinskā un mana iestāde, kurā es strādāju uz dzelzcel̦a, likvidējas, un kad mēs beigsim likvidāciju, tad nezinu, ko ar mums darīs. Un tad vin,as man stellējās priekšā, ka vingas ir slepenās, un viena bija no Pēterpils studente un otra bija studente turpat no Ribinskas. Un vin,as apgādā cara virsniekiem privātās drēbes. Un viņas man uzticējās, un es tad biju viñām sabiedrotā. Es bieži pie viñām gāju. ${ }^{37}$ (Adelīna Rozīte, dzimusi Sniedze, intervēta 1992. gadā Straumēnos, Anglijā.)

Savukārt Rozālijas Adleres dzimšanas gads (1902) l̦auj atmin̄ām iesniegties valsts vēsturē svarīgos notikumos, kad risinājās cīņas par Latvijas neatkarību. Rozāliju Adleri intervēju Daugavas Vanagu namā Londonā, kur vina strādāja.

Kad tie bermontieši gāja ārā, tad atkal bija tāds notikums. Es stāvēju rindā pēc maizes Bolderājā, un es dzīvoju Daugavgrīvā. Un tas bija apmèram ap vienpadsmitiem dienā, kad mēs tādā lielā rindā stāvējām. Un tad pienāca viens vācu virsnieks un pateica - pēc 15 minūtēm būs pirmie šāvieni tajā Bolderājāa, tur bija tā atkāpšanās. Un mēs pat nedabūjām no tās rindas iziet, kad sākās jau tie pirmie šāvieni... Un es skrienu uz tilta, lai tiktu pāri uz mājām, un tur jau krìt bumbas. [..]

Un tad tie bermontieši no Daugavgrīvas sāka atkāpties, un tad jau nāca latvieši iekšāa, laikam no Jürmalas puses... Un tad tie jau arī bija dikti trūcīgi, viniem zābaku nebija... Un es tā atceros, ka bija rudens un es vēl tās brāla drēbes nesu uz kuǵa viniem. Vini ar kugi cēlās pāri uz Rīgu. Tur jau bija arī liellaivas, un $k \bar{a}$ tur viņi visādīgi... Un tad vini brauca un dziedāja to dziesmu "Cel mani pār pa Daugavu...", kā jau jaun̄̄bā, tas man vienmēer tā palicis atmin̄ā.. ${ }^{38}$ (Rozālija Adlere, dzimusi 1902. gadā Rīgā, intervēta 1992. gadā Londonā.)

Sofijas Dravnieces (dzimusi 1895. gadā Dundagā) atmiņas l̦auj iejusties Pirmā pasaules kara bēgḷu ceḷā, ko latviešu literatūrā aprakstījusi Anna Brigadere.

\footnotetext{
${ }^{37}$ NMV-57.

38 NMV-58.
} 
Ja esat lasījusi Brigaderes romānu Kvēlošā lokā, kā tur tā bēgšana aprakstīta, tad gluži tāpat bija. [..] Mès sākām vieni no Ārlavas baznīcas, bet mums jau šur un tur pievienojās. No katra cel̦a nāk ārā un pievienojās. [..] Un interesanti, $k a$ brauc viens virs ar vienzirga ratiem un vinam ir zārks tais ratos. Neko citu vinam neredzēja, bet zārks bija.

Tad jau bija brauciens, rati pie ratiem. [..] Lopi bija grāvjos atstāti, netikuši līdzi. Mantas atstātas grāvjos. Tie visi devās uz Rīgu. Tad sāka lìt lietus, diezgan stipri lija, tad līdām zem ratiem, mantas salija. [..]

Tā nu dzinām taisni pa liedagu, gar pašu jūras malu. Tad uzreiz viens tel̦š iet jūrā iekšāa. Un citi vinam pakal̦. Un tik brien, brien arvien dziļāk un arvien tālāk. Tad bija lielas mokas, lai dabūtu vinus atkal ārāa. ${ }^{39}$ (Sofija Dravniece, dzimusi 1895. gadā Dundagā, intervēta 1993. gadā Talsos.)

Kā Pirmā pasaules kara gaita ietekmējusi ebreju dzīvi Latvijā, atceras Elizars Rabinovičs.

Piecpadsmitā gadā ap aprīḷa mēnesi vācieši ienāca Kurzemē, Liepājā. Un virspavēlnieks, Nikolajs N,ikolajevičs, k,eizara onkulis, teica, ka ebreji varbūt palìdzēs vāciešiem. To, ka tur dzīvoja baroni un pilsētas vācieši, birgeri, Kurzemē, un uz laukiem vācieši, to vin̄̌s neskaitīja, bet ebreji tirgotāji, amatnieki - tie var būt nodevēji. Un mūs, ebrejus, evakuēja.

Tã evakuēšana nebija barga. Tur mums deva dzīvokli, krievi labi mūs pieņēma. Un mēs gājām katrs strādāt, naudu pelnīt. Es biju Maršanskā Tambovas apgabalā. Es gāju mācìties par atslēdznieku. Un vēl mācījos vakaros, papildināju krievu valodas zināšanas, mācījos grāmatvedību. Es pabeidzu tos kursus un aizgāju strādāt par grāmatvedi, un nostrādāju lìdz 22. gadam, un tad mēs aizbraucām uz Latviju ar visu gimeni kop $\bar{a}^{40}$

Elizars Rabinovičs skaidri atceras garā mūža epizodes, jo sevišķi tās, kurās redz zīmīgas sakarības. Otrā pasaules karā viņš atgriezās no sarkanarmijas un nav tiešais holokausta liecinieks, tomēr pārmantotā atmina ietekmē attieksmi pret kara beigās novēroto.

39 NMV-81.

40 NMV-803.
Armijā biju lìdz kara beigām. Pēdējais, kas man palika atmin̄ā: 9. maijā agri no rīta es noskatījos, kā gāja kolonna ar vācu oficieriem - vinus veda gūstā, un to kolonnu veda, bija tās priekšgalā mūsu oficieris pēc uzvārda Amdurs, ebrejs, kapteinis Amdurs. Ebrejs veda vācu oficierus gūstā (smejas). ${ }^{41}$

\section{Paaudžu mantojums}

Daudzos dzīvesstāstos atklājas, cik liela nozīme iepriekšējai paaudzei, kuras izglītība, darba pieredze un redzesloks spēj dot drošību un paver perspektīvu arī bērniem. Vairākos atmiņu stāstos raksturota atgriešanās pēc Pirmā pasaules kara un revolūcijas ar Krievijā nopelnīto kapitālu.

Bērnības atminas iezīmē 20. gadsimta agresīvo sākumu, kas jau agri rada priekšstatu par šausmām, nežēlību un par to, ko nozīmē apvērsums ${ }^{42}$.

Man iznāca taisni visādi tādi apvērsumi Vladivostokā. Rakstīt es jau mācēju, es zinu, ka māsa mani mācīja un es avīzēs jau lasīju kaut ko tur. Un grāmata tur arī bija atsūtīta latviešu valodā, kur bija tas Raina dzejolītis "Mazs kakīitis, mazs zak̦ītis uz ceḷa satikās un brīnijāas". Tas bija tas, ko es pirmo latviešu valodā iemācījos. Bet skolā mani tur nelaida, jo bija šausmīgi nemieri. Es runāju krieviski, bet, kad uz ielas kaut kāda šaudīšanās bija, cilvēku līki tur gulēja, es teicu: "N̦e hoču perevarota, ņe hoču perevarota! ${ }^{43}$ " 44 (Margarita Sidere, dzimusi 1913. gadā Vladivostokā, intervēta 1992. gadā Latvijā.)

Posāmies atgriezties brīvā Latvijā, mūsu pašu zemē. Pienāca brīdis sēsties sarkanajos lopu vāgosos, atkal ar mātes sausiņu maisu. Braucām pārpildītos vāgos, gulējām visi uz lāvām. Brauciens ilga vairākus mēnešus. Gar dzelzceḷa malām redzējām kaudzēs saliktus līkus - kara un tīfa upurus. ${ }^{45}$ (Aleksandra

\footnotetext{
41 NMV-803.

42 Apvērsums - radikālas sociālpolitiskas pārmainas.

43 Negribu apvērsumu! - kriev.

44 NMV-112.

45 Turpat.
} 
Eiche, dzimusi 1905. gadā Omskā, intervēta 1996. gadā Zviedrijā.)

Vecākajiem atmiṇu stāstītājiem gadsimts sākas ar pašu pieredzētām jukām, bailēm, neskaidrību, bet nākamajai paaudzei ir raksturīgi stāsti par drošības sajūtu, ko sniedz vecāku zināšanas, kultūras apvārsnis un nereti Krievijā sastrādātais kapitāls.

Tēvs Krievijā tika pie naudas un zināmas turības, bet ienāca lielinieki un viss - cauri! Tie latvieši tur daži jau bija diezgan kreisi. Bet têvvs - vin̄š pats bij grūti strādājis, bija tāds humāns. Viṇ̌̌ dzirnavās bij ieviesis jau astoṇu stundu darbalaiku. Têvs l,oti gādāja par tiem saviem strādniekiem, un tāpēc tie savlaicīgi pateica, lai bēg projām. Un tā viņš sakrāva, cik var kamanās, un aizbrauca ${ }^{46}$ (Kness Kņezinskis, dzimis 1903. gadā Petropavlovskā, intervēts 1999. gadā ASV.)

Apvērsums nupat vēl plaukstošiem latviešu uzṇēmējiem, mājskolotājiem lika ne tikai glābt dzīvību, bet arī domāt par ǵimenes nākotni. Dažādos slepenos veidos tiek vests pāri robežai Krievijā nopelnītais.

Un tad... to kannu. Mēs, bèrni, jau to nemaz nezinājām, kas tur ir un ka tur ir. Tikai tad, kad atbraucām uz Viḷāniem, tad paps tai kannai attaisīja nevis te no augšas, no vāka, bet no dibena taisīja val̦ā. Kad to rokturi pārvīlēja pušu, i tad dabūjām redzêt, kas tur ir saglabāts. Vot, un kad paps nomira divdesmit piektajā gadā, tad mums bija dzelzs zelta rezerve. Bija, ar ko dzīvot, saprotat. ${ }^{47}$ (Valerians Viḷčuks, dzimis 1910. gadā Pēterburgā, intervēts 1990. gadā Rīgā.)

Veltas Skultānes vecāki, sagaidījuši meitas piedzimšanu 1920. gadā, brauc no Tomskas uz Latviju, kas kḷuvusi par neatkarīgu valsti. Ģimene brauc atsevišksā vagonā, kas iztapsēts ar zvērādām, lai glābtos no sala braucienā, kas ilga pusgadu. Līdzi vesta lāde ar drēbēm un metāla gulta. Kad tēvs Rīgā noīrējis dz̄̄vokli, tur ienes arī metāla gultu un no kājām izkrata ārā zelta rubḷus, kas sapelnīti Krievijā. Ar to tad pakāpeniski tēvs sāk saimniekot,

\footnotetext{
46 NMV-771.

47 NMV-5.
}

nodrošina ǵimenei labklājību un var ieguldīt bērnu izglītošanā. 1940. gadā tēva dz̄ive tiek trağiski pārtraukta. Bērni un māte kḷūst trimdinieki, bet tēva paraugs un ieguldījums meitas audzināšanā ḷauj pārvarēt grūtības un garīgi stiprina nākamo paaudzi. Anglijā uzaug un iegūst izglītību Veltas meita Vieda, kas saraksta grāmatas $^{48}$ un tagad vada mutvārdu vēstures pētījumu Latvijā.

Atmiņas par notikumiem, kas iespaidojuši cilvēku dzīvi Latvijā, plašākai sabiedriskai apzināšanai var nodot institucionāli - ar muzeju, bibliotēku starpniecību. Tomēr visos gadījumos tas notiek ar ieinteresētu cilvēku entuziasmu, kas, līdzīgi kā Benita Kalniņa, uzñemas misiju atkarot aizmirstībai traǵisko likteņu stāstus. Viņas ǵimene, tāpat kā daudzas citas, nebija gatava vardarbībai, kas iznīcināja tēvu, noveda nāvē māti. Benita ar brāli atgriezās un savus mūža gadus, personīgos līdzekḷus veltīja, lai sakopotu tuvākā un tālākā novada vardarbīgi iznīcināto ǵimeņu atmiņas. Atmiņu modināšana nāca reizē ar valsts neatkarības atjaunošanu, un daudzās ǵimenēs, nerunājot par sabiedrību kopumā, tikai pakāpeniski atklājās vardarbības tālejošās sekas un iespaids uz nākamajām paaudzēm.

Es jau savus vecākus ar nesaprotu. Kā varēja no savām mājām iziet, tā kā stāv, ar plikām kājām. Kaut kādas vasaras tupelītes, čībingas kājās un neviena drēbes gabala līdz, nekā. Kad mūs izveda, man bij pilni desmit gadi, vienpadsmitais. Es pilnīgi visu sapratu. Naktī viņi ielauzās, tas man visu mūžu atmin̄ā paliks. Ienāca te iekš̄â. Es jau dzirdēju, biju pamodusies. Dzirdēju, ka [runā] svešāa, kaut kādā nesaprotamā balsī, nesaprotamā valodā. Tad mamma ienāca mūs modināt. Mamma saka, celieties, mīlie bērniņi, mums jābrauc prom.

Mēs visi tādi satrūkušies. Viņa paņem mazo brālīti, iznes ārā, un mēs vēl kā pusaizmiguši pa tām gultināam vēl čubināmies. Tad ienāk kaut kādi vīri iekšā un uzreiz izrauj no mazā brālǐša gultinas gultasmaisu. Mès gulējām uz salmu maisiniem. Visi salmi izbirst pa zemi. Meklē ieročus. Vai tad bērns gulētu uz ieročiem! ${ }^{49}$ (Benita Kalniņa,

\footnotetext{
${ }^{48}$ Skultans, Vieda 1998, 2007.

49 NMV-3125.
} 
dzimusi 1929. gadā Praulienas pagastā, intervēta 2004. gadā Rīgā.)

Biogrāiskā metode caur individuālās pieredzes stāstiem veido priekšstatu par pētāmo parādību sakņojumu subjektīvajā attieksmē un atškirīīgajā uztverē. Subjektīvās vēstures liecības atklāj arī, kāda nozīme cilvēku dzīvē bijusi notikumiem, cik dziḷs ir to emocionālais iespaids, kā cilvēks apzinās notikušo un kā caur to izteic savas vērtîbas un kultūras identitāti. Arī to, kā stāstījumā izpaužas iepriekšējo paaudžu ietekme.

\section{Nobeigums}

Analizējot NMV krājumā apkopotos dz̄̄vesstāstus, stāstītāja piederību paaudzei var noteikt, pamatojoties ne tikai uz tajos aplūkoto pieredzi un attēlotajiem laika posmiem, bet arī uz stāstījuma veidu un valodu, izteiksmes līdzekḷu lietojumu, sniegumu. Aplūkotie piemēri raksturo 20. gadsimta sākumā dzimušo stāstītāju izteiksmes veidu, kas sakņojies sava laika kultūras vidē, sākot no ǵimenē mantotā līdz plašākām sabiedriskām ietekmēm. Katrā atminuu stāstījumā atklājas laikmetu un līdz ar to paaudzi raksturojošas kultūras saites. Paaudzes iezīmē arī tādas nianses kā vecāku dotie kristītie personu vārdi, piem., Alvīne, Valida, Rozālija, Adelīna. Katrs no tiem liecina par izvēli, kas bijusi aktuāla noteiktā laika posmā. Paaudzi apvieno laikmets ar tādām iezīmēm kā tehnikas sasniegumi, mode, ekonomiskās attiecības, gan arī - ar pretrunīgām idejām un politiskiem strāvojumiem.

Dzīvesstāsti apliecina, ka piederību paaudzei neietekmē politiskie uzskati. Konfliktu gadījumā vienai paaudzei pieder gan tie, kas atbalsta, gan tie, kas norobežojas vai neatzīst kāda laikmeta politiskās vēstures metanaratīvu. Neatkarīgi no uzskatiem sociālie satricinājumi un pierastās dzīves lūzums atstāj iespaidu uz visas paaudzes dzīvi.

Paaudžu pieredzes apgūšana ir svarīga, lai katrs cilvēks un sabiedrība kopumā spētu vērtêt savu vietu un lomu procesā, kas balstās uz pārbaudītām morālām vērtībām. To sekmē talantīgi literatūras un mākslas darbi, saistoši atmiņu sniegumi un arī Nacionālās mutvārdu vēstures krājums - kā neatkārtojams tekstu masīvs savā veselumā un spējā aizvien no jauna uzrunāt sabiedrību. Svarīgi, lai notiek kustība, lai atmiņas tiktu pieprasītas un uzklausītas, un, gluži kā prožektora staru kūlis, izgaismotu savu laikmetu iepriekšējo paaudžu pieredzes salīdzinājumā.

Paaudžu perspektīvā svarīga ir Astrīdas Erlas atziṇa par to, ka atmiṇa beidz pastāvēt, ja tā nepārceḷ, turklāt ne tikai horizontāli vienas paaudzes robežās, bet, galvenais, - paaudžu mijas vertikālē. Pieredzes pārnesums notiek, kad dzīvesstāstā pārredzamas divu un pat triju paaudžu senās atmiņas kā paša pieredzes dạ̦a. Atminuu pārvietošanās gimenes lokā cilvēku ietekmē daudz personīgāk, intīmāk nekā ar ārējo atminuu nesēju (vēsturisko filmu, literāro sacerējumu, zinātnisko pētîjumu) starpniecību un sekmē morāles principu tālāknodošanu, kas tautas pastāvēšanai ir pati svarīgākā vēstures stāsta dalia. Atmiṇu ceḷošana gan šaurākā, gan plašākā lokā ir nepieciešama sabiedrības ētiskā kodola dzīvotspējai.

Raksts tapis Latvijas Zinātnes padomes fundamentālo un lietišķo pêtījumu projekta Nr. 1zp-2018/1-0458 Atminu pārnese starp paaudzèm: naratīvā perspektīva un LU prioritārā projekta Kritiskā domāšana, inovācija, konkurētspēja un globalizācija ietvaros. 


\section{VĒRES}

Austin, J. L. (1975) How to Do Things With Words. 2nd ed. Cambridge : Harvard University Press.

Barts, R. (2012) Teksta bauda. Rīga : Mansards.

Bauman, R. (1989) American Folklore Studies and Social Transformation: A Performance Centered Perspective. Text and Performance Quarterly, 9 (3), 175-184.

Bela, B.; Garda-Rozenberga, I.; Zirnīte, M. (2016) Migratory memories between Latvia and Sweden. Oral History, 44, 2 (Autumn), 69-80. Pieejams: http://www.academia.edu/34783815/Migratory_memories_ between_Latvia_and_Sweden.

Bula, D. (2011) Mūsdienu folkloristika: paradigmas maina. Rīga : Zinātne, 211-238.

Erll, A. (2011) Travelling Memory. Parallax, 17, 4, 4-18, doi:10.1080/13534645.2011.605570.

Gāle-Kārpentere, I. (1994) Trimda kā dzīves attīstības modelis. Latvijas Zinātṇu Akadēmiskās Vēstis, 4 (561), 19-24.

Ikstena, N. (2015) Mātes piens. Rīga : Dienas Grāmata.

Jāgo, T. (2007) Pagātnes un laika interpretācijas pētīšana no pārmantojamās vēstures viedokḷa. Zirnīte, M. (sast.) Spogulis: Dzīvesstāsti: vēsture, kultūra, sabiedrība. Rīga : LU Filozofijas un sociolog̣ijas institūts, Dzīvesstāsts.

Jākobsons, V. (2006) Trejādas brokastis. Rīga.

Kalniņa, B. (2008) Stāsta pārbraukušie.

Knağis, I. (2016) Ne mēs tos laikus izdomājām. Rīga.

Līce, A. (1990-2008) Via Dolorosa. Rīga : Liesma.

Mannheim, K. (1952) The Problem of Generations. Kecskemeti, Paul (ed.) Essays on the Sociology of Knowledge: Collected Works, 5. New York : Routledge, 276-322.

Skultans, V. (2007) Empathy and Healing: Essays in Medical and Narrative Anthropology; Oxford, New York Berghahn Books.

Skultāne, V. (2007) Mutvārdu vēstures pētīšanas nozīmīgums Latvijā. Zirnīte, Māra (sast.) Spogulis: Dzīvesstāsti: vēsture, kultūra, sabiedrība. Rīga : LU Filozofijas un socioloğijas institūts, Dzīvesstāsts, 34-50.

Skultans, V. (1998) The Testimony of Lives: Narrative and Memory in Post-Soviet Latvia. London, New York : Routledge.

Urtāns, V. (2015) Par ko?: 1941.14.VI-1946.4.IX. Rīga : Nordik.

Vanaga, M. (1991) Veḷupes krastā. Rīga : Liesma; Vanaga, Melānija (1995-1998) Dvēseḷu pulcēšana. Rīga : Karogs. 